メカニカルアロイングした Ti-Al-Cr 合金の焼結組織

小林 慶三, 三輪 謙治, 高柳 猛

通産少工業技術院名古屋工業技術試験所， 4462 名古屋市北区平手町1-1.

\title{
Microstructures of Mechanical Alloyed Ti-Al-Cr Alloy after Sintering
}

Keizo Kobayashi, Kenji Miwa and Takeshi Takayanagi

Government Industrial Research Institute Nagoya, Hirate-cho Kita-ku, Nagoya 462.

Received December 18, 1992

\begin{abstract}
Mechanical alloying for Ti-Al-Cr mixture of elemental powders was performed by a vibrational ball mill in Ar atmosphere under reduced pressure. The effect of $\mathrm{Cr}$ addition for mechanical alloying process was studied by $X$-ray diffraction and SEM. The microstructure of mechanical alloyed $\mathrm{Ti}-\mathrm{Al}-\mathrm{Cr}$ alloy after sintering was studied by optical microscope and EPMA.

An addition of $\mathrm{Cr}$ made particle size of mechanical alloyed powder fine and sintering easy. Mechanical alloyed Ti-Al-Cr alloy containing 4 6 mass\% $\mathrm{Cr}$ had needlelike crystals of $\mathrm{Ti}_{3} \mathrm{Al}$ after sintering at $1673 \mathrm{~K}$ for $1.2 \mathrm{ks}$.
\end{abstract}

\section{1 緒 言}

金属間化合物TiA1は，軽量でかつ耐熱性にも優れ ているため次世代の高温構造用枋料としての応用が 期待されている。しかし，TiAlは勒性にそしく実用 化のためには，第 3 元索の添加や組織の微細化によ る常温延性の改善が必要である。なかです，Crはそ の有力な添加元素であり，鋳造材料を中心に研究が 行われている”．一方， Ti とAlの卖粉末を出発原料 とし，乾式にて混合・粉碎を行うメカニカルアロイ ング (以下MAと記す) 法は，鋳造材料に比べTiA1の 結晶粒径を細かくできる゙2ため, 延性の改善方法と して期待されている，本研究では，Ti，A1，Crの索粉
末を出発原料としMA法により合成を行い，MA粉末に 及ぼす添加Crの影響およびMA粉末を烧結した場合に 得られるTi-A1-Cr合金の焼結組織について調べたの で報告する。

\section{2 試料およひ実験方法}

Al量が34mass\%になるよう調整したTi粉末（純度 99mass\%) とA1粉末（純度 99.5 mass\%) の混合粉末に， Cr粉末 (純度 99mass\%) を全粉末重量の0，2，4，6，8， 10.20mass\%添加し, 乳鉢にて予備混合を行った。こ の粉末を振動型ボールミル に にて720ksのMA処理を減 圧A r票囲気下で行った。MA処理は、ステンレス製容 


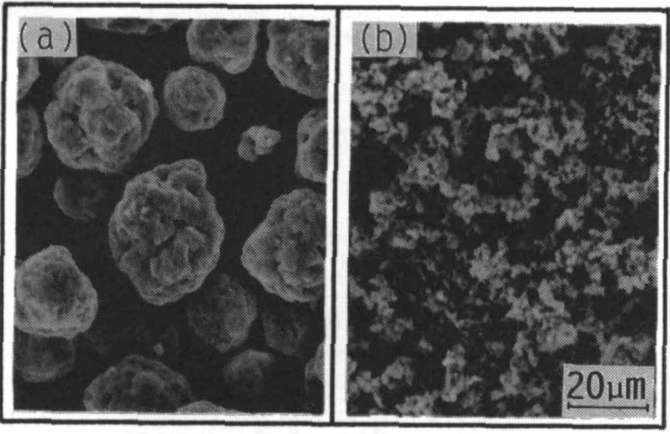

Photo. 1 SEM micrographs of (a)Ti-34mass\%AI and (b)Ti-32mass\%Al-6mass\%Cr powders mechanical alloyed for $720 \mathrm{ks}$ in $\mathrm{Ar}$ atmosphere under reduced pressure.

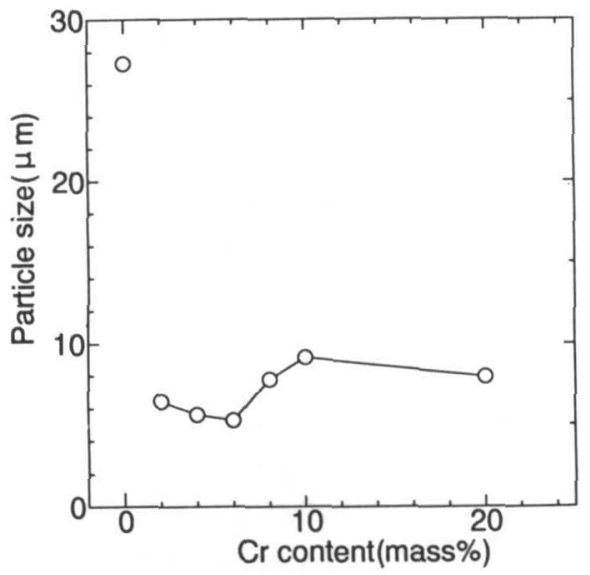

Fig. 1 Effect of $\mathrm{Cr}$ content on the average particle size of mechanical alloyed $\mathrm{Ti}-\mathrm{Al}-\mathrm{Cr}$ powders.

器に10фのステンレス製ボールを粉末重量 : ボール 重量が $1 ： 14$ になるように入れ，1 回の粉末配合 重量は8gとした。ボールとの焼き付き防止剂は特に 添加しなかった。得られたMA粉末は窒素雾囲気のグ ローブボックス内で取り出し，SE M 観察, 粒度分 布測定, X 線回折に供した。また, MA粉末を $320 \mathrm{MPa}$

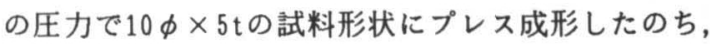
$35 \mathrm{kPa}$ の減圧 $\mathrm{Ar}$ 雾囲気中 $1673 \mathrm{~K}$ で1.2 ks焼結を行った. 得られた焼結体は研磨後, 光学顕微鏡による組織観 察，EPMAによる成分分析に供した。

\section{3実験結果およひ考察}

MA処理後の粉末の S E M 写真をphoto. 1に, Cr添加

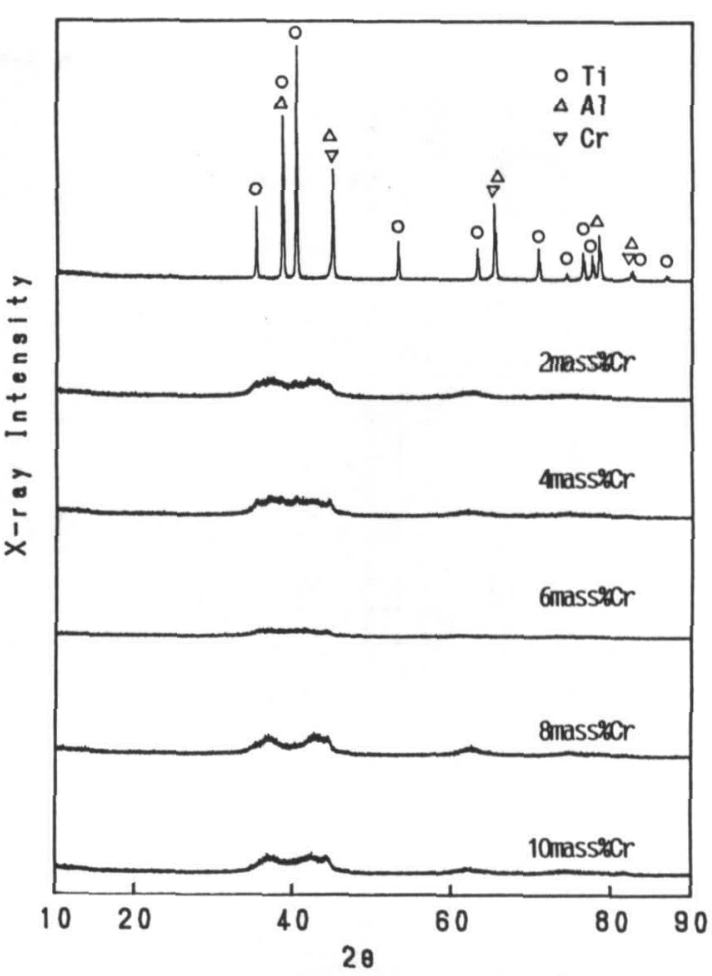

Fig. 2 X-ray diffraction patterns of $\mathrm{Ti}-\mathrm{Al}-\mathrm{Cr}$ powders mechanical alloyed for $720 \mathrm{ks}$ in Ar atmosphere under reduced pressure.

量の違いによるMA処理後の粉末の平均粒径の変化を Fig.1に示す.Crを添加しなかったTi-34mass\%Al組成 のMA粉末では平均粒径が $27 \mu \mathrm{m}$ と粗くなっており, S E M 観察結果から細かい粉末が圧着され, 凝集体 を形成していることがわかった。これに対し，Crを 添加した試料ではこのような凝集体の形成は認めら れず, MA粉末の平均粒径す $5 \sim 9 \mu \mathrm{m}$ 程度であった. また, $\mathrm{Cr}$ の添加量によるMA粉末の平均粒径の違いは ほとんど認められない。

720 ksMA処理した粉末のX 線回折パターンをFig. 2 に示す．乳鉢で混合しただけの試料（4mass\%Cr添加 試料) では $T \mathrm{i}, \mathrm{Al}, \mathrm{Cr}$ のピークが観察されるが， $720 \mathrm{k}$ s間のMA処理によりいずれあかなりブロードなピーク となっている．ただ，8mass\%以上Crを添加した試料 では新たなピークが形成されつつあり，MAによる新 しい相の合成が生じつつあるあのと考えられる。こ れらのMA粉末をD S Cにより分析を行うと，いずれ あ結晶化に相当する顕著なピークは認められなかっ た.このことから，これらの粉末はMA処理によりア モルファス化はしておらず，微細分散の状態である 


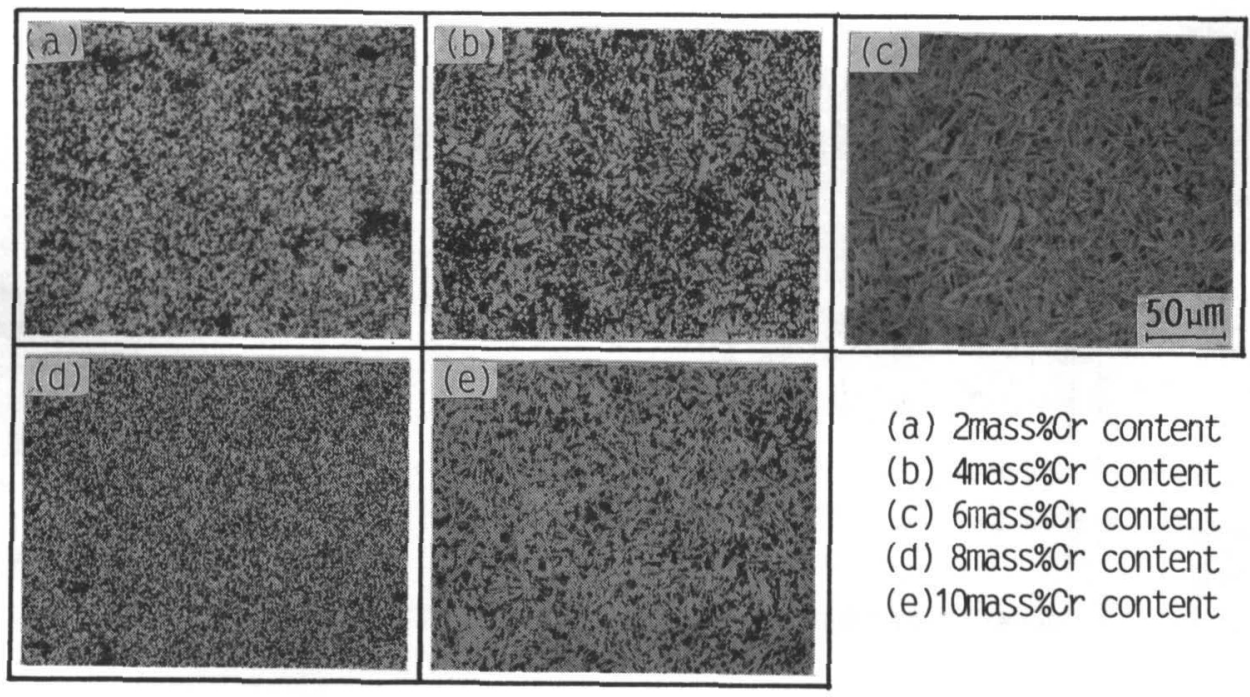

Photo. 2 Microstructures of mechanival alloyed $\mathrm{Ti}-\mathrm{Al}-\mathrm{Cr}$ sintered at $1673 \mathrm{~K}$ for $1.2 \mathrm{ks}$ in $\mathrm{Ar}$ atmosphere under reduced pressure.

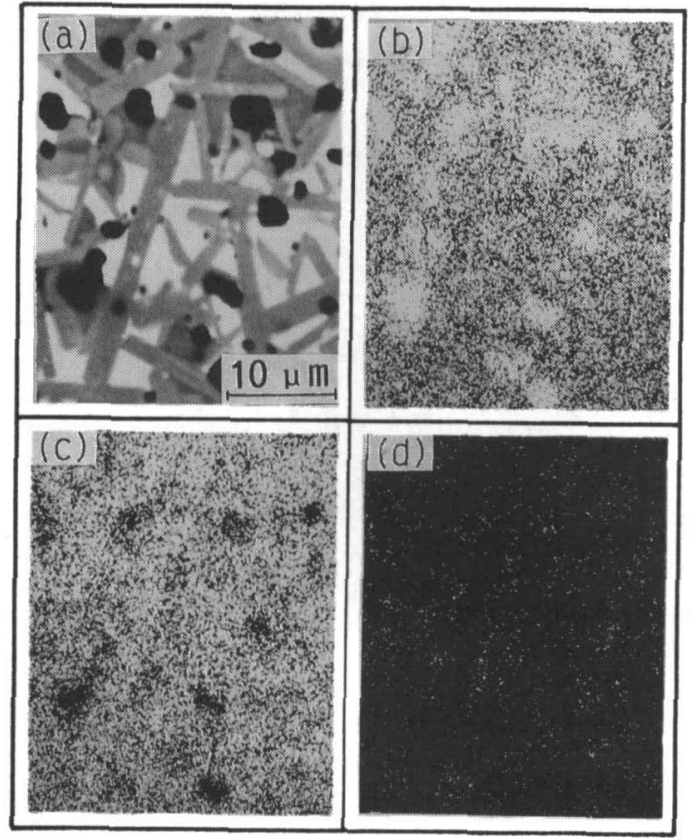

Photo. 3 EMA analysis of mechanical alloyed Ti-32mass\%AI-6mass\% 1673K for 1. 2ks.

(a)Compo image, (b)Al-Ka, (c) Ti-Ka, (d) $\mathrm{Cr}-\mathrm{Ka}$

\section{と考えられる。}

MA粉末をプレス成形後, 焼結した試料の光学顕微 鏡組織をPhoto. 2 に示す. MA粉末が凝集体を形成して いたCrを添加していない試料では, 焼結により凝集 体内は緻密になっているが, 凝集体粒子間にわたる 焼結は本焼結条件において生じていなかった。また, Crを20mass\%添加した試料は, 本焼結条件では全く焼 結していなかった。 しかし, Crを10mass\%以下添加し たMA粉末の焼結では, かなり緻密な焼結体が得られ た. Poto. 2の組織の中でCrを4〜 6mass\%添加した試料 では, 異方性結晶を有する組織となった。この異方 性を有する結晶は, 組織から考えて板状ではなく, 棒状の結晶であろうと考えられる.この棒状の結晶 を同定するため，6mass\%Crを添加した焼結体を E P M A による面分析を行った. 結果をPhoto. 3 に示す. 棒状の結晶は, TiとAlより構成されており, Crが含 まれていないことがわかる，さらに，E P M Aによ る定量分析を行ってみると，この相はTiを81.4mass \%,Alを17.4mass\%, コンタミによるFeを1. 2 mass\%程 度含んでおり， $\mathrm{Ti}_{3} \mathrm{Al}$ であろうと考えられる。MA粉末 においては, そのX線回折パターンからあTi, Al, Cr が微細に分散した状態であると考えられるが, その 焼結過程においてはCrを含まないTi ${ }_{3} \mathrm{Al}$ が生成したこ とになる、なお, MA容器やボールからのFeのコンタ ミはCr添加量が多くなるほど増加する傾向にあるが, 
10mass\%Cr添加の場合でも1.4mass\%程度であった.

Ti とCr (Ti-6mass\%Cr), Al とCr (Al-11mass\%Cr) をそれぞれ720ks間本実験と同じ条件でMA処理し，X 線回折を行ってみると,AlとCrではMAによる変化は ほとんど認められない。しかし，TiとCてではMA反他 が進行し，かなりブロードなピークとなる。このこ とから，Ti，Al，CrをMAした場合にも，TiとCrのMA反 応が進行しており，丁iが活性な状態になっているこ とが推察される。すなわち，Ti，Al，CrのMA粉末にお いては，焼結時にA1の溶解が始まりこの溶融A1中 に活性な Tiが拡散し、規則化温度の最も低いTis $\mathrm{s}$ 名 生成するものと考えられる。このTis $\mathrm{A} A 1$ は $0_{1}$ 。の結晶 構造であるためhcp結晶構造のように特定方向に成長 し，棒状の結晶となったものと考えられる。

Crを添加しなかったMA粉末と焼結体が異方性結晶 を有する組織を示した4mass\%Cr添加のMA粉末と6mas s\%Cr添加のMA粉末を $1723 \mathrm{~K}$ まで20K/minの昇温速度で D T A 分析してみるとほぼ同じ曲線を描くが, 4 mas s\%Cr添加の試料および6mass\%Cr添加の試料では，13 $65 \mathrm{~K}$ 付近に発熱ピークが認められる。この温度以下で 焼結した試料では, 焼結が不十分であり棒状の結晶 あ認められない。また，この温度以上で焼結した4〜 6mass\%Crを添加した試料では，1673Kで焼結した時に 認められた棒状の結晶とほぼ同一組成の結晶が認め られた。このことから，1365K付近においてこの結晶 が生成し，Crが4〜 6mass\%添加された試料にのみ発現 するものと考えられる。このような結晶は，Ti-32. 6mass\%Al-4mass\%Crを溶解・凝固させた場合には観察 されないことから，出発原料にMA粉末を用いたこと
による特異な現象であり，溶解法で一般にみられる ラメラ構造のTiA1 とは異なった特性が期待されるる のと考えられる。また，MA粉末を焼結した本試料に おいては，溶解材料でみられるようなTi $2 \mathrm{AlCr}$ は観察 されなかった。

$$
4 \text { まとめ }
$$

Ti，Al，Crの索粉末を720ksのMA処理を行い, 得られ た粉末を減圧Ar雽团気下で焼結した結果, 以下の結 論が得られた。

(1)Ti，A1の菜粉末をMA処理すると凝集体が形成され， 粉末の粒度が粗くなってしまうが, Crを添加するこ とによりMA処理した粉末は教集体が少なくなり粒度 る細かくなる。また，10mass\%以下のCr添加量の場合， Ti-A1-Cr合金の焼結性は问上する.

(2)Ti:A1の重量比が66:34になるようにしたTi，A1，C rの卖粉末をMA処理した後焼結すると，Crを4〜6mas s\%添加した焼結体において異方性結昆を有する組織 が得られた。この棒状の結晶は，MAにより活性化し たTi と溶融Alにより生成されたTiっAlである。

\section{文 嘀}

1) S. C. Huang, E. L. Hall and D. S. Shih: ISIJ, 31 (1991) 1000.

2) 扛畸宏樹, 杉本春彦, 眙山恵, 時実正治: 粉体および粉末治金, 38(1991)914.

3)小林度三, 阪口康司, 加藤清隆, 二宮三男, 野崎佳彦, 太田英明, 水野俊之: 名古屋工業技術試験所報告, $39(1990) 433$. 